\title{
Perovskite-type $\mathrm{La}_{0.6} \mathrm{Sr}_{0.4} \mathrm{Co}_{0.2} \mathrm{Fe}_{0.8} \mathrm{O}_{3}, \mathrm{Ba}_{0.5} \mathrm{Sr}_{0.5} \mathrm{Co}_{0.2} \mathrm{Fe}_{0.8} \mathrm{O}_{3}$, and $\mathrm{Sm}_{0.5} \mathrm{Sr}_{0.5} \mathrm{Co}_{0.2} \mathrm{Fe}_{0.8} \mathrm{O}_{3}$ cathode materials and their chromium poisoning for solid oxide fuel cells
}

\author{
Fengyu Shen ${ }^{*}$ and Kathy Lu*
}

Department of Materials Science and Engineering, Virginia Tech, VA 24061, USA

\begin{abstract}
In the pursuit for solid oxide fuel cell (SOFC) cathode materials that can operate over a wide temperature range, especially at low temperatures such as $600{ }^{\circ} \mathrm{C}$, perovskite structure materials $\mathrm{La}_{0.6} \mathrm{Sr}_{0.4} \mathrm{Co}_{0.2} \mathrm{Fe}_{0.8} \mathrm{O}_{3}$ (LSCF), $\mathrm{Ba}_{0.5} \mathrm{Sr}_{0.5} \mathrm{Co}_{0.2} \mathrm{Fe}_{0.8} \mathrm{O}_{3}$ (BSCF), and $\mathrm{Sm}_{0.5} \mathrm{Sr}_{0.5} \mathrm{Co}_{0.2} \mathrm{Fe}_{0.8} \mathrm{O}_{3}$ (SSCF) are studied. Their electrochemical performance is compared by electrochemical impedance spectroscopy (EIS) at $600{ }^{\circ} \mathrm{C}, 700{ }^{\circ} \mathrm{C}$ and $800{ }^{\circ} \mathrm{C}$ for $100 \mathrm{hrs}$ through an AISI 441 interconnect/cathode/yttria-stabilized zirconia (YSZ) electrolyte half-cell structure. The BSCF cathode has the smallest polarization resistance at $600{ }^{\circ} \mathrm{C}$, closely followed by the SSCF cathode; the LSCF cathode has the smallest polarization resistance working at $700{ }^{\circ} \mathrm{C}$; the $\mathrm{SSCF}$ cathode has the smallest polarization resistance working at $800{ }^{\circ} \mathrm{C}$, closely followed by the LSCF cathode. From $600-800{ }^{\circ} \mathrm{C}, \mathrm{SrCrO}_{4}$ phase forms on the $\mathrm{SSCF}$ cathodes near the interconnect while $\mathrm{BaCrO}_{4}$ phase forms on the BSCF cathodes near the interconnect. For the LSCF cathodes, however, $\mathrm{SrCrO}_{4}$ phase is only detected at $700{ }^{\circ} \mathrm{C}$ and $800{ }^{\circ} \mathrm{C}$. $\mathrm{Cr}$ species diffusion to and poisoning of the cathodes do not directly correlate with the half-cell performance. Lattice constant, stoichiometry, particle size, $\mathrm{Cr}$ deposition, and working temperature are important factors to consider.
\end{abstract}

\footnotetext{
* Corresponding author. 309A Holden Hall, Materials Science and Engineering Department, Virginia Tech, Blacksburg, VA 24061, USA. Tel.: +1 540231 3225; Fax: +1 5402318919 .

Email address: kris2013@vt.edu (F.Y. Shen); klu@vt.edu (K. Lu).
} 
Keywords: LSCF; BSCF; SSCF; Cathode; Solid oxide fuel cell

\section{Introduction}

Mixed ionic-electronic conductors are promising cathode materials for solid oxide fuel cells (SOFCs), considering that the oxygen reduction reaction is not just limited to the triple-phase boundary (TPB) sites between electrolyte, cathode, and gas but can be extended to two-phase boundary sites between the cathode and gas [1-4]. They also have much higher oxygen ionic conductivity than the conventional $(\mathrm{LaSr}) \mathrm{MnO}_{3}$ cathode material $[5,6]$.

Iron-cobalt-based $\mathrm{ABO}_{3}$ perovskite oxides are promising cathode materials for intermediate temperature SOFCs because of their high electronic conductivity and high oxygen reduction activity based on disorder-free oxygen ion migration mechanism [7]. Among them, $\mathrm{La}_{0.6} \mathrm{Sr}_{0.4} \mathrm{Co}_{0.2} \mathrm{Fe}_{0.8} \mathrm{O}_{3}$ (LSCF) and $\mathrm{Ba}_{0.5} \mathrm{Sr}_{0.5} \mathrm{Co}_{0.2} \mathrm{Fe}_{0.8} \mathrm{O}_{3}$ (BSCF) are frequently reported [8, 9]. Park et al. reported total resistance of $0.55 \Omega \cdot \mathrm{cm}^{2}, 0.86 \Omega \cdot \mathrm{cm}^{2}$, and $1.56 \Omega \cdot \mathrm{cm}^{2}$ at $730{ }^{\circ} \mathrm{C}$, $680{ }^{\circ} \mathrm{C}$, and $630{ }^{\circ} \mathrm{C}$ respectively for a Ni-YSZ/YSZ/GDC/LSCF cell [10]. Shao et al. obtained low area specific resistance of $0.055-0.071 \Omega \cdot \mathrm{cm}^{2}$ at $600{ }^{\circ} \mathrm{C}$ and $0.51-0.60 \Omega \cdot \mathrm{cm}^{2}$ at $500{ }^{\circ} \mathrm{C}$ with BSCF as the cathode and SDC as the electrolyte $[11,12] . \mathrm{Sm}_{0.5} \mathrm{Sr}_{0.5} \mathrm{Co}_{0.2} \mathrm{Fe}_{0.8} \mathrm{O}_{3}$ (SSCF) is also a cathode material and can be obtained through Sm substitution of $\mathrm{Ba}$ in BSCF; however, this material has not gained much attention. Lv et al. showed that the polarization resistance of SSCF is $0.17 \Omega \cdot \mathrm{cm}^{2}$ at $800{ }^{\circ} \mathrm{C}$ with $\mathrm{La}_{0.8} \mathrm{Sr}_{0.2} \mathrm{Ga}_{0.8} \mathrm{Mg}_{0.2} \mathrm{O}_{3}$ as the electrolyte [13]. So far, there has been no systematic comparative study of these three cathodes working at different temperatures.

Chromia-forming alloy is the most commonly used metallic interconnect material due to their high electronic conductivity, high thermal conductivity, easy workability, and low cost [1416]. However, Cr poisoning can cause dramatic electrochemical performance degradation of 
cathodes [17, 18]. With the continuing interest of developing new cathode materials, understanding their interaction tendency and mechanism with $\mathrm{Cr}$ species is needed in order to develop Cr-tolerant cathode materials. In addition, high SOFC operation temperature causes the degradation of cathode materials and the reaction at the interface of cathode and interconnect [19]. Lowering working temperature of SOFCs is one of the major objectives for its commercialization. The behaviors of new cathodes at different operating temperature need to be understood.

This study is focused on the different thermophysical and electrochemical characteristics of these three cathode materials: LSCF, BSCF, and SSCF. Their electrochemical performance at $600{ }^{\circ} \mathrm{C}, 700{ }^{\circ} \mathrm{C}$, and $800{ }^{\circ} \mathrm{C}$ is analyzed in order to identify the optimal cathode material at different operating temperature. The crystal structures and microstructures of the cathodes after the thermal testing are examined in order to explain and understand their electrochemical behaviors. The effect of the AISI 441 interconnect on the cathode performance is also discussed.

\section{Experimental procedures}

\subsection{Chemicals}

$\mathrm{La}\left(\mathrm{NO}_{3}\right)_{3} \cdot 6 \mathrm{H}_{2} \mathrm{O}, \mathrm{Sr}\left(\mathrm{NO}_{3}\right)_{2}, \mathrm{Co}\left(\mathrm{NO}_{3}\right)_{2} \cdot 6 \mathrm{H}_{2} \mathrm{O}, \mathrm{Fe}\left(\mathrm{NO}_{3}\right)_{3} \cdot 9 \mathrm{H}_{2} \mathrm{O}, \mathrm{Ba}\left(\mathrm{NO}_{3}\right)_{2}, \mathrm{Sm}\left(\mathrm{NO}_{3}\right)_{3} \cdot 6 \mathrm{H}_{2} \mathrm{O}$ ethylenediaminetetraacetic acid, citric acid, $\mathrm{NH}_{4} \mathrm{NO}_{3}$, sucrose, and $\mathrm{NH}_{3} \cdot \mathrm{H}_{2} \mathrm{O}$ were purchased from Alfa Aesar (Ward Hill, MA). $\alpha$-terpineol as solvent was purchased from Sigma-Aldrich (St. Louis, MO). Microcrystalline cellulose as a pore forming agent was purchased from Spectrum Chemical Manufacturing Corporation (Gardena, CA). Ethyl cellulose as a binder was purchased from Acros Organics (Morris Plains, NJ). YSZ was purchased from Nextech Materials (Lewis 
Center, OH). AISI 441 was produced by ATI Allegheny Ludlum Corporation (Brachenridge, PA).

\subsection{Synthesis of LSCF, BSCF, and SSCF powders}

LSCF powder was synthesized by a combustion method as described elsewhere [20]. The molar ratio of $\mathrm{La}\left(\mathrm{NO}_{3}\right)_{3} \cdot 6 \mathrm{H}_{2} \mathrm{O}, \mathrm{Sr}\left(\mathrm{NO}_{3}\right)_{2}, \mathrm{Co}\left(\mathrm{NO}_{3}\right)_{2} \cdot 6 \mathrm{H}_{2} \mathrm{O}$, and $\mathrm{Fe}\left(\mathrm{NO}_{3}\right)_{3} \cdot 9 \mathrm{H}_{2} \mathrm{O}$ was 6:4:2:8 and the molar ratio of metal ions, ethylenediaminetetraacetic acid (EDTA), citric acid, ammonium nitrate, sucrose was $2: 1: 2: 10: 0.75$. In the first step, the metal nitrates were dissolved in distilled water in a beaker; EDTA, citric acid, ammonium nitrate, and sucrose were added. The $\mathrm{pH}$ value was adjusted by ammonium hydroxide to 6 to completely dissolve EDTA. With the usage of a mesh on the top of a beaker the solution was placed in a pre-heated furnace at $450{ }^{\circ} \mathrm{C}$. After 10 minutes the combustion process was completed and the beaker was taken out to cool down. The reaction equation was as follows [21]:

$0.6 \mathrm{La}\left(\mathrm{NO}_{3}\right)_{3}+0.4 \mathrm{Sr}\left(\mathrm{NO}_{3}\right)_{2}+0.2 \mathrm{Co}\left(\mathrm{NO}_{3}\right)_{2}+0.8 \mathrm{Fe}\left(\mathrm{NO}_{3}\right)_{3}+\mathrm{C}_{10} \mathrm{H}_{16} \mathrm{~N}_{2} \mathrm{O}_{8}+2 \mathrm{C}_{6} \mathrm{H}_{8} \mathrm{O}_{7}+$ $10 \mathrm{NH}_{4} \mathrm{NO}_{3}+0.7 \mathrm{C}_{11} \mathrm{H}_{22} \mathrm{O}_{11}+14.15 \mathrm{O}_{2} \rightarrow \mathrm{La}_{0.6} \mathrm{Sr}_{0.4} \mathrm{Co}_{0.2} \mathrm{Fe}_{0.8} \mathrm{O}_{3}+13.7 \mathrm{~N}_{2}+44.25 \mathrm{H}_{2} \mathrm{O}+$ $30.25 \mathrm{CO}_{2}$

The combusted powder was calcined at $900{ }^{\circ} \mathrm{C}$ for $2 \mathrm{hrs}$ and milled before use. For the synthesis of BSCF and SSCF powders, the above procedure was followed with the exception of the raw materials and molar ratios of metal ions. $\mathrm{La}\left(\mathrm{NO}_{3}\right)_{3} \cdot 6 \mathrm{H}_{2} \mathrm{O}$ was substituted by $\mathrm{Ba}\left(\mathrm{NO}_{3}\right)_{2}$ and $\mathrm{Sm}\left(\mathrm{NO}_{3}\right)_{3} \cdot 6 \mathrm{H}_{2} \mathrm{O}$ for $\mathrm{BSCF}$ and SSCF respectively. The final LSCF, BSCF, and SSCF stoichiometries were $\mathrm{La}_{0.6} \mathrm{Sr}_{0.4} \mathrm{Co}_{0.2} \mathrm{Fe}_{0.8} \mathrm{O}_{3}, \mathrm{Ba}_{0.5} \mathrm{Sr}_{0.5} \mathrm{Co}_{0.2} \mathrm{Fe}_{0.8} \mathrm{O}_{3}$, and $\mathrm{Sm}_{0.5} \mathrm{Sr}_{0.5} \mathrm{Co}_{0.2} \mathrm{Fe}_{0.8} \mathrm{O}_{3}$. The LSCF stoichiometry had the best compromise between high electrical conductivity and good thermal expansion coefficient (TEC) match with the electrolyte material [22]. The BSCF and 
SSCF stoichiometries showed the highest electrical conductivity and crystal structure stability $[13,23]$.

\subsection{Electrical conductivity test}

For electrical conductivity measurement, the powders of LSCF, BSCF, and SSCF were cold pressed at $200 \mathrm{MPa}$ into cylindrical pellets $(12.7 \mathrm{~mm}$ in diameter and about $6 \mathrm{~mm}$ in thickness) using an uniaxial press. The green pellets were further sintered at $1300^{\circ} \mathrm{C}, 1150{ }^{\circ} \mathrm{C}$, and $1250{ }^{\circ} \mathrm{C}$ for $10 \mathrm{hrs}$ at a heating/cooling rate of $5{ }^{\circ} \mathrm{C} \cdot \mathrm{min}^{-1}$ respectively. Ag-Pd paste was subsequently painted onto both sides of the pellets as electrodes. The electrical conductivities were measured in air by a four-probe DC potentiostat (VersaSTAT 3, Princeton Applied Research, Oak Ridge, $\mathrm{TN})$. The voltage was scanned from 0 to $1 \mathrm{~V}$ and the corresponding current was evaluated over a temperature range of $300-900{ }^{\circ} \mathrm{C}$.

\subsection{Assembly of AISI 441/cathode/YSZ structure}

The cathode material (56.8 wt $\%)$ was mixed and ball-milled with microcrystalline cellulose (5.7 $\mathrm{wt} \%$ ), ethyl cellulose (1.1 $\mathrm{wt} \%)$, and $\alpha$-terpineol (36.4 wt $\%$ ) for $1 \mathrm{hr}$ to make pastes for screen printing. The prepared pastes were screen printed on $8 \mathrm{~mol} \% \mathrm{YSZ}$ substrates, using a \#330 mesh. The screen printed pastes were square-like with $\sim 0.5 \mathrm{~cm}^{2}$ area. The cathode/YSZ structure was kept at $200{ }^{\circ} \mathrm{C}$ for $3 \mathrm{hrs}$ and at $400{ }^{\circ} \mathrm{C}$ for $1 \mathrm{hr}$ to partially burn the binder and solvent and was then kept at $950{ }^{\circ} \mathrm{C}$ for $2 \mathrm{hrs}$ to complete binder removal and bond with YSZ; a heating and cooling rate of $1{ }^{\circ} \mathrm{C} \cdot \mathrm{min}^{-1}$ was used.

AISI 441 ferritic stainless steel pieces were used as the interconnect material and were cut

into square substrates (area: $10 \times 10 \mathrm{~mm}^{2}$ ). In order to remove the oxidized layer and obtain a 
scratch free flat surface, the steel pieces were polished to optical finish and ultrasonically cleaned with water and ethanol. The polished AISI 441 alloy piece was placed on the cathode side and the configuration was shown in our previous paper [24].

\subsection{Thermal treatment under current load}

In order to investigate the electrochemical behaviors of the LSCF, BSCF, and SSCF cathodes, the AISI $441 /$ cathode/YSZ half-cells were heated to $600{ }^{\circ} \mathrm{C}, 700{ }^{\circ} \mathrm{C}$, and $800{ }^{\circ} \mathrm{C}$ respectively, using a tube furnace (1730-20 HT Furnace, CM Furnace Inc. Bloomfield, NJ) in dry air environment. Afterwards, the half-cells were cathodically polarized using a potentiostat (VersaSTAT 3, Princeton Applied Research, Oak Ridge, TN). A platinum mesh was placed inbetween the porous cathode layer and the AISI 441 interconnect to optimize the current distribution, and the electrodes were connected by Pt wires with a Pd paste. The working electrode was positioned at the center of the YSZ electrolyte with about the same area as the cathode. The reference electrode was painted as a ring around the working electrode. The counter electrode was positioned at the center of the interconnect and the reference electrode was painted on the edge. A load was applied between the YSZ electrolyte and the AISI 441 interconnect to achieve good contact. The EIS testing program used was a multi-loop process with the frequency from $100 \mathrm{kHz}$ to $0.025 \mathrm{~Hz}$. The amplitude was $10 \mathrm{mV}$. After that, a current density of 200 $\mathrm{mA} \cdot \mathrm{cm}^{-2}$ was applied to mimic the working condition of an actual fuel cell. EIS data were recorded every 2 hrs during the thermal treatment.

\subsection{Characterization and performance testing}


X-ray diffraction (XRD, X'Pert PRO diffractometer, PANalytical B.V., EA Almelo, The Netherlands) analysis was employed to characterize the crystal structure of the synthesized powders. The microstructures of the cathodes before and after the thermal treatment were examined by a field-emission scanning electron microscope (FESEM, LEO (Zeiss) 1550, Oberhochem, Germany) with a carbon layer applied before imaging.

\section{Results and Discussion}

\subsection{Electrochemical behaviors}

The electrical conductivities of LSCF, BSCF, and SSCF in air were measured in the temperature range of $300-900{ }^{\circ} \mathrm{C}$ as shown in Fig. 1. The conductivities here were extracted to full density values by considering the relative densities of the corresponding cylindrical pellets. LSCF has the largest electrical conductivity while BSCF has the smallest electrical conductivity. The detailed values are shown in Table 1. Overall, the electrical conductivities first increase and then decrease with the measurement temperature for these three cathode materials. The maximal electrical conductivities are located between $600-700{ }^{\circ} \mathrm{C}$ for the three electrode materials. As a comparison, the electrical conductivity for the classical cathode material $\mathrm{La}_{0.7} \mathrm{Sr}_{0.3} \mathrm{MnO}_{3}$ is reported to be $110 \mathrm{~S}^{\cdot} \mathrm{cm}^{-1}$ at $800{ }^{\circ} \mathrm{C}$ [25], which is only higher than that of BSCF but much lower than those of LSCF and SSCF. This means these cathode materials have high application potentials.

The conductivity difference of these three cathode materials can be understood as follows.

The ionic radii of $\mathrm{Sm}^{3+}, \mathrm{La}^{3+}$, and $\mathrm{Ba}^{2+}$ are $1.24 \AA, 1.36 \AA$, and $1.61 \AA$ respectively. Smaller ionic radius means smaller lattice constant for the same crystal structure. In general, the electrical conductivity from the smaller unit cell is greater than that from the larger unit cell. Here, BSCF 
and SSCF have the same stoichiometry and the ionic radius of $\mathrm{Ba}^{2+}$ is larger than that of $\mathrm{Sm}^{3+}$, so the conductivity of BSCF is smaller than that of SSCF. For LSCF (6:4:2:8), its electrical conductivity is affected also by its different stoichiometry from BSCF and SSCF $(5: 5: 2: 8)$ and cannot be compared directly.

Since the above conductivity measurement is from direct current mode, it can only provide ohmic resistance information for the cathodes. In order to understand the fundamental process in different half-cells and correlate the electrochemical behaviors with the cathode evolution, equivalent circuit $\mathrm{R}_{\Omega}\left(\mathrm{R}_{\mathrm{H}} \mathrm{CPE} \mathrm{E}_{\mathrm{H}}\right)\left(\mathrm{R}_{\mathrm{L}} \mathrm{CPE} \mathrm{E}_{\mathrm{L}}\right)$ under $\mathrm{AC}$ mode, shown in our previous work [26], has been used to fit the EIS spectra and obtain deconvoluted arcs at different frequencies. In the circuit, $\mathrm{R}_{\Omega}$ is the ohmic resistance from the cathode, the Pt wires, the Pd paste, the contact between each layer and the cathode, and the electrolyte; however, the major contribution and especially the changes are from the contact resistance between each layer, and the electrolyte. $\mathrm{R}_{\mathrm{H}}$ and $\mathrm{R}_{\mathrm{L}}$ refer to the polarization resistances at high and low frequencies, while $\mathrm{CPE}_{\mathrm{H}}$ and $\mathrm{CPE}_{\mathrm{L}}$ are constant phase elements corresponding to each frequency range. The high frequency resistance $\mathrm{R}_{\mathrm{H}}$ corresponds to $\mathrm{O}^{2-}$ incorporation into the electrode and its transport in the cathode; and the low frequency resistance $\mathrm{R}_{\mathrm{L}}$ in the impedance spectra is attributed to oxygen adsorption and dissociation as well as its surface diffusion [27].

Considering that the cathode requires time to activate and stabilize at intended working temperatures, the electrochemical data after the initial starting points are more representative of the cathode behaviors. Accordingly, the Nyquist plots and the fitting results with two arcs after 2 hrs of testing are presented in Fig. 2 to demonstrate the fundamental difference of the cathode materials. Fig. 2(a) shows the electrochemical behavior of the LSCF cathode under a current density of $200 \mathrm{~mA} \cdot \mathrm{cm}^{-2}$ at $600{ }^{\circ} \mathrm{C}, 700{ }^{\circ} \mathrm{C}$, and $800{ }^{\circ} \mathrm{C}$ after $2 \mathrm{hrs}$ of the thermal treatment. With 
the working temperature increase, the ohmic resistance decreases from $7.1 \Omega \cdot \mathrm{cm}^{2}$, to $2.5 \Omega \cdot \mathrm{cm}^{2}$, and to $0.9 \Omega \cdot \mathrm{cm}^{2}$ and the polarization resistance (sum of $R_{H}$ and $R_{L}$ ) decreases dramatically from $47.0 \Omega \cdot \mathrm{cm}^{2}$, to $3.2 \Omega \cdot \mathrm{cm}^{2}$, and to $2.1 \Omega \cdot \mathrm{cm}^{2}$. From $600{ }^{\circ} \mathrm{C}$ to $700{ }^{\circ} \mathrm{C}$, the ohmic resistance decreases the most, which is partly attributed to the ohmic resistance decrease of the YSZ electrolyte, as YSZ has poor ionic conductivity at $600{ }^{\circ} \mathrm{C}$. More importantly, the polarization resistance drastically decreases from $47.0 \Omega \cdot \mathrm{cm}^{2}$ to $3.2 \Omega \cdot \mathrm{cm}^{2}$. This is because its catalytic activity for oxygen exchange reaction and the ionic conductivities of the cathode and the electrolyte are enhanced. Fig. 2(b) shows the electrochemical behavior of the BSCF cathode after $2 \mathrm{hrs}$ of the thermal treatment. With the working temperature increase, the ohmic resistance decreases from $20.3 \Omega \cdot \mathrm{cm}^{2}$, to $5.8 \Omega \cdot \mathrm{cm}^{2}$, and to $2.5 \Omega \cdot \mathrm{cm}^{2}$ and the polarization resistance decreases gradually from $10.0 \Omega \cdot \mathrm{cm}^{2}$, to $2.8 \Omega \cdot \mathrm{cm}^{2}$, and to $2.0 \Omega \cdot \mathrm{cm}^{2}$. Again, the drastic ohmic resistance decrease can be partly attributed to the ohmic resistance decrease of the YSZ electrolyte. The large polarization resistance decrease from $10.0 \Omega \cdot \mathrm{cm}^{2}$ to $2.8 \Omega \cdot \mathrm{cm}^{2}$ is due to the enhanced catalytic activity for the oxygen exchange reaction and the ionic conductivities of the LSCF cathode and the YSZ electrolyte. Fig. 2(c) shows the electrochemical behavior of the SSCF cathode after $2 \mathrm{hrs}$ of the thermal treatment. With the working temperature increase, the ohmic resistance decreases from $11.2 \Omega \cdot \mathrm{cm}^{2}$, to $3.6 \Omega \cdot$, and to $2.5 \Omega \cdot \mathrm{cm}^{2}$ and the polarization resistance decreases gradually from $21.4 \Omega \cdot \mathrm{cm}^{2}$, to $3.0 \Omega \cdot \mathrm{cm}^{2}$, and to $1.8 \Omega \cdot \mathrm{cm}^{2}$. Again, the ohmic resistance decrease is partly due to the ohmic resistance decrease of the YSZ electrolyte. In addition, the decreased contact resistance with the working temperature increase also contributes to the lower ohmic resistance for all the cathodes. The polarization resistance decrease is due to its higher catalytic activity for the oxygen exchange reaction and higher conductivities of SSCF and YSZ at elevated temperatures. 
With the acknowledgment of the ohmic resistance contribution from other cell components, the relative magnitude of the total ohmic resistance is consistent with the ohmic resistance for individual cathode materials shown in Fig. 1. The LSCF cathode has the smallest ohmic resistance at all temperatures due to its largest electrical conductivity among all three materials, while the BSCF cathode has the largest ohmic resistance due to its smallest electrical conductivity. The oxygen vacancy concentration is determined by the stoichiometry of the cathode. The polarization resistance difference can be partially explained based on the oxygen vacancy. Here, for LSCF, BSCF, and SSCF, their oxygen vacancy concentrations can be calculated to be $6.7 \%, 16.7 \%$, and $8.3 \%$ respectively based on the chemical stoichiometries. Higher oxygen vacancy concentration from BSCF means higher oxygen ionic conductivity and lower polarization resistance, as shown in Fig. 2.

To better understand the electrochemical performance of the cathodes, the polarization resistance changes with time are shown in Fig. 3. Fig. 3(a) is for $600{ }^{\circ} \mathrm{C}$ testing temperature and all the polarization resistances at this temperature first decrease dramatically and then stabilize, which can be related to the slow cathode activation at $600{ }^{\circ} \mathrm{C}$, taking about $50 \mathrm{hrs}$ for the three cathodes to achieve their optimal performance. After $50 \mathrm{hrs}$ of the thermal treatment, BSCF and SSCF have about the same low polarization resistance of $5 \Omega \cdot \mathrm{cm}^{2}$ while LSCF has much higher polarization resistance of $8 \Omega \cdot \mathrm{cm}^{2}$. Fig. 3(b) is for the $700{ }^{\circ} \mathrm{C}$ results and all the polarization resistances first decrease and then increase gradually. At this temperature, the cathodes are activated in about $6 \mathrm{hrs}$, which is much faster than that at $600{ }^{\circ} \mathrm{C}$. After that, the small polarization resistance increases are believed to be from cathode degradation and chromium deposition, which will be explained in Section 3.2. Among them, LSCF has the smallest polarization resistance and SSCF has the largest polarization resistance. Fig. 3(c) is for the 
$800{ }^{\circ} \mathrm{C}$ results and all the polarization resistances first increase dramatically and then stabilize/increase gradually. At this temperature, no drop in polarization resistances is observed, which means the activation process completes in $2 \mathrm{hrs}$ at $800{ }^{\circ} \mathrm{C}$. It is possible that the higher operating temperature accelerates cathode degradation, microstructure change, and chromium deposition, resulting in large polarization resistances after the cathode activation [28, 29]. This can explain why the LSCF and BSCF cathodes have larger polarization resistances when working at $800{ }^{\circ} \mathrm{C}$ than working at $700{ }^{\circ} \mathrm{C}$. Among them, SSCF has the smallest polarization resistance in long term operation, while BSCF has the largest polarization resistances at $800{ }^{\circ} \mathrm{C}$.

Based on Fig. 3, it can also be stated that in the long term use of the SOFCs, the electrochemical performance of the cathodes is different from their initial state. The cathode performance is not only affected by their intrinsic properties, such as electrical conductivity and oxygen vacancy concentration, but also by their microstructure evolution and interaction with other foreign species, which will also be discussed in Section 3.2.

The polarization resistances for the three cathodes after working at $600{ }^{\circ} \mathrm{C}, 700{ }^{\circ} \mathrm{C}$, and $800{ }^{\circ} \mathrm{C}$ for $100 \mathrm{hrs}$ are shown in Table 2. The polarization resistance of the BSCF cathode (5.1 $\left.\Omega \cdot \mathrm{cm}^{2}\right)$ is the smallest and comparable to the SSCF cathode $\left(6.0 \Omega \cdot \mathrm{cm}^{2}\right)$ at $600{ }^{\circ} \mathrm{C}$; the polarization resistance of the LSCF cathode $\left(3.3 \Omega \cdot \mathrm{cm}^{2}\right)$ is the smallest at $700{ }^{\circ} \mathrm{C}$; the polarization resistance of the SSCF cathode $\left(4.5 \Omega \cdot \mathrm{cm}^{2}\right)$ is the smallest and comparable to the LSCF cathode $\left(4.6 \Omega \cdot \mathrm{cm}^{2}\right)$ at $800{ }^{\circ} \mathrm{C}$. Overall, BSCF is preferred for working at $600{ }^{\circ} \mathrm{C}$; LSCF is preferred for working at $700{ }^{\circ} \mathrm{C}$; and SSCF is preferred for working at $800^{\circ} \mathrm{C}$.

\subsection{Microstructures}


The microstructures of the cathode/interconnect interface after $100 \mathrm{hrs}$ of the thermal treatment at $600{ }^{\circ} \mathrm{C}, 700{ }^{\circ} \mathrm{C}$, and $800{ }^{\circ} \mathrm{C}$ are shown in Fig. 4. Figs. 4(a), (b), and (c) are for the LSCF, BSCF, and SSCF cathodes respectively before testing. As expected, all the electrode layers are porous. The initial particle sizes of LSCF, BSCF, and SSCF are about $100 \mathrm{~nm}, 400 \mathrm{~nm}$, and $50 \mathrm{~nm}$ respectively. Usually, smaller particle size means larger specific surface area, and thus larger double-phase-boundary (DPB) and triple-phase-boundary (TPB). This is to say, smaller particles are desired for better electrochemical performance. For the LSCF cathode, after $100 \mathrm{hrs}$ at $600{ }^{\circ} \mathrm{C}$ (Figs. 4(d)), a few larger particles appear, of which the size is about $300 \mathrm{~nm}$. At $700{ }^{\circ} \mathrm{C}$ for $100 \mathrm{hrs}$ (Fig. $4(\mathrm{~g})$ ), there are more large particles forming at about $500 \mathrm{~nm}$. At $800{ }^{\circ} \mathrm{C}$ for $100 \mathrm{hrs}$ (Fig. 4(j)), the larger particles keep coarsening and the size is around $1 \mu \mathrm{m}$. For the BSCF cathode (Figs. 4(b), (e), (h), and (k)), at $600{ }^{\circ} \mathrm{C}$ for $100 \mathrm{hrs}$, the cathode becomes denser but the particles do not coarsen. At $700{ }^{\circ} \mathrm{C}$ and $800{ }^{\circ} \mathrm{C}$ after $100 \mathrm{hrs}$ respectively, the particles also stay about the same, which is partly ascribed to the larger starting particle size. For the SSCF cathode (Figs. 4(c), (f), (i), and (1)), at $600^{\circ} \mathrm{C}$ for $100 \mathrm{hrs,} \mathrm{many} \mathrm{large} \mathrm{particles} \mathrm{can} \mathrm{be}$ seen and their size is about $400 \mathrm{~nm}$. The same happens for the SSCF cathode working at $700{ }^{\circ} \mathrm{C}$. At $800{ }^{\circ} \mathrm{C}$, the large particles coarsen to $1 \mu \mathrm{m}$. The other particles still maintain their original size.

$\mathrm{XRD}$ is used to examine the phase evolution after $100 \mathrm{hrs}$ of the thermal treatment (Fig. 5). The main peaks at (110) direction are located at $32^{\circ}$ for $\mathrm{BSCF}, 32.7^{\circ}$ for $\mathrm{LSCF}$, and $33^{\circ}$ for SSCF, which demonstrates the peak shift from right to left for SSCF, LSCF, and BSCF. The lattice constants of the SSCF, LSCF, and BSCF powders can be calculated to be $3.85 \AA, 3.87 \AA$, and $3.95 \AA$, which are in agreement with earlier reports $[13,21,30]$. This result shows that replacing $\mathrm{La}$ with $\mathrm{Ba}$ increases the lattice constant of the perovskite crystal structure for about 
2.1\%; while replacing La with $\mathrm{Sm}$ decreases the lattice constant of the perovskite crystal structure for about $0.5 \%$. It has to be admitted that the more ratio of $\mathrm{La}^{3+}$ to $\mathrm{Sr}^{2+}$ in $\mathrm{LSCF}$ makes its lattice constant decreases a little. Thus, the actual lattice constant increase for replacing La with $\mathrm{Ba}$ is less than $2.1 \%$ and the actual decrease for replacing La with Sm is larger than $0.5 \%$.

Fig. 5(a) shows the evolution of the LSCF cathode. After working at $600{ }^{\circ} \mathrm{C}$ for $100 \mathrm{hrs}$, only LSCF peaks are detected. For the cathodes tested at $700{ }^{\circ} \mathrm{C}$ and $800{ }^{\circ} \mathrm{C}$, however, $\mathrm{SrCrO}_{4}$ phase is found. This is consistent with the SEM results, indicating that $\mathrm{Cr}$ deposition on the LSCF surface is through interaction with $\mathrm{Sr}$ rather than with $\mathrm{La}, \mathrm{Co}$, or Fe. Our previous work has also demonstrated that these large particles are $\mathrm{SrCrO}_{4}$ and they mainly reside on the surface of the cathode $[31,32]$. The formation of the poorly conductive $\mathrm{SrCrO}_{4}\left(1.8 \times 10^{-5}\right.$ and $1.8 \times 10^{-4}$ $\mathrm{S} \cdot \mathrm{cm}^{-1}$ at $700{ }^{\circ} \mathrm{C}$ and $800{ }^{\circ} \mathrm{C}$ respectively [33]) increases the electrode ohmic resistance by blocking the electrical conductivity path. Also, $\mathrm{SrCrO}_{4}$ formation extracts $\mathrm{Sr}$ species from the LSCF lattice, leading to Sr deficiency at the A-site. Thus the electrical conductivity of LSCF is further reduced. As a result, the activity of the LSCF cathode for the oxygen reduction reaction and DPB are reduced substantially. This process is embodied by the significant increase in $R_{p}$ of LSCF after activation. The absence of $\mathrm{SrCrO}_{4}$ formation at $600{ }^{\circ} \mathrm{C}$ also explains the slight polarization resistance increase shown in Fig. 3(a). At $700{ }^{\circ} \mathrm{C}$ and $800{ }^{\circ} \mathrm{C}$, however, the polarization resistance increases substantially. Fig. 5(b) shows the evolution of the BSCF cathode. Instead of $\mathrm{SrCrO}_{4}, \mathrm{BaCrO}_{4}$ phase is detected. $\mathrm{BaCrO}_{4}$ is reported to be more stable compared to $\mathrm{SrCrO}_{4}$ [33]. Therefore, the $\mathrm{Cr}$ deposition $\left(\mathrm{CrO}_{3}, \mathrm{Cr}_{2} \mathrm{O}_{3}\right)$ on the $\mathrm{BSCF}$ takes place by interacting with $\mathrm{Ba}^{2+}$ rather than with $\mathrm{Sr}^{2+}$ with the presence of $\mathrm{BaO}$. The extraction of $\mathrm{Ba}^{2+}$ species from the BSCF cathode can also reduce the activity of the BSCF cathode for the oxygen reduction reaction and DPB substantially, supported by the significant increase in $\mathrm{R}_{\mathrm{p}}$ of BSCF 
after activation. The formation of $\mathrm{BaCrO}_{4}$ phase does prevent the reaction of $\mathrm{Sr}^{2+}$ with the poisonous $\mathrm{CrO}_{3}$ vapor or $\mathrm{Cr}_{2} \mathrm{O}_{3}$. Moreover, the extraction of the $\mathrm{Ba}$ species from the $\mathrm{BSCF}$ lattice leads to Ba deficiency at the A-site and changes its stoichiometry, leading to the cathode performance degradation. The electrical conductivity of $\mathrm{BaCrO}_{4}$ has been reported to be $4.5 \times 10^{-3}$ $\mathrm{S} \cdot \mathrm{cm}^{-1}$ at $800{ }^{\circ} \mathrm{C}$, which is almost 25 times higher than that of $\mathrm{SrCrO}_{4}$ [33]. Fig. 5(c) shows the evolution of the SSCF cathode. It is similar to that of the LSCF cathode, moreover, $\mathrm{SrCrO}_{4}$ phase is formed on the cathode after working at $600{ }^{\circ} \mathrm{C}$ for $100 \mathrm{hrs}$, indicating that SSCF is more susceptible to $\mathrm{Cr}$ poisoning than LSCF because the smaller ionic radius of $\mathrm{Sm}^{3+}$ cannot retain $\mathrm{Sr}^{2+}$ in the lattice structure as well. The easy and fast $\mathrm{Cr}$ accumulation on the cathode surface for SSCF causes faster polarization resistance increase (shown in Figs. 3(b) and (c)) after its activation, compared with LSCF. For all the cathodes, very weak $\mathrm{SrO}_{2}$ peaks are detected due to the degradation of cathodes $[15,34]$. Moreover, no XRD peaks of $\mathrm{La}_{2} \mathrm{Zr}_{2} \mathrm{O}_{7}$ or $\mathrm{SrZrO}_{3}$ are detected when the three cathodes are removed from the YSZ substrate, which means the reaction between the cathodes and the substrate is not serious. These electrical performance changes can be ascribed to the cathodes.

\subsection{Fundamental cathode behaviors}

Based on the above results, the factors affecting the electrochemical performance of the cathodes can be summarized as follows:

Lattice constant: Smaller lattice constant means larger electrical conductivity, leading to smaller ohmic resistance.

Stoichiometry: Stoichiometry affects the electrical conductivity and oxygen vacancy concentration. Higher oxygen vacancy usually means higher ionic conductivity. 
Stoichiometry also affects lattice constant and crystal structure stability. Usually, more atoms in A-site means smaller lattice constant.

> Particle size: Smaller particle size means larger DPB and TPB, leading to smaller $\mathrm{R}_{\mathrm{p}}$.

$>\mathrm{Cr}$ deposition: $\mathrm{Cr}$ deposition increases polarization resistance through formation of $\mathrm{SrCrO}_{4}$ on LSCF and SSCF and $\mathrm{BaCrO}_{4}$ on BSCF, which decrease their conductivity and oxygen vacancy. TPB and DPB are blocked by Cr deposition. SSCF is more prone to Cr deposition.

$>$ Temperature: Higher working temperature means faster cathode activation, microstructure evolution, and more $\mathrm{Cr}$ deposition, leading to faster increase of $\mathrm{R}_{\mathrm{p}}$. The peak conductivities for all three cathodes are around $600-700{ }^{\circ} \mathrm{C}$.

The above five factors affect the electrochemical performance of the cathodes through conductivity, oxygen vacancy, TPB, and DPB. An illustration of their interrelationship is shown in Fig. 6. Lattice constant can be changed through elemental substitution, to a certain extent stoichiometry variation, and extraction of cations from the cathodes. Stable crystal structure is essential for high electrochemical performance. Particle size is usually determined by the synthesis temperature and the intrinsic properties of the material; smaller particle sizes increase TPB and DPB but may make the cathode more susceptible to degradation. Cr deposition decreases cathode performance through extraction of Sr for LSCF and SSCF and Ba for BSCF, forming poor conductive phases, especially for the LSCF and SSCF cathodes. Higher temperature accelerates initial cathode activation but also $\mathrm{Cr}$ deposition, leading to worse electrochemical performance for the cathodes in short term operation. 
As explained above, besides cathode degradation, $\mathrm{Cr}$ deposition also decreases the electrochemical performance of cathodes. The $\mathrm{Cr}$ deposition process in the LSCF, BSCF, and SSCF systems can be expressed as follows [35]:

In the LSCF and SSCF systems (Sr segregation):

$$
\begin{aligned}
& \mathrm{CrO}_{3}(\mathrm{~g})+\mathrm{SrO}(\mathrm{s}) \rightarrow \mathrm{Cr}-\mathrm{Sr}-\mathrm{O}(\text { nuclei }) \\
& \mathrm{Cr}-\mathrm{Sr}-\mathrm{O}(\text { nuclei })+\mathrm{CrO}_{3}(\mathrm{~g}) \rightarrow \mathrm{Cr}_{2} \mathrm{O}_{3}(\mathrm{~s}) \\
& \mathrm{Cr}_{2} \mathrm{O}_{3}(\mathrm{~s})+\mathrm{CrO}_{3}(\mathrm{~g})+\mathrm{SrO}(\mathrm{s}) \rightarrow \mathrm{SrCrO}_{4}(\mathrm{~s})
\end{aligned}
$$

In the BSCF system (Ba segregation):

$$
\begin{aligned}
& \mathrm{CrO}_{3}(\mathrm{~g})+\mathrm{BaO}(\mathrm{s}) \rightarrow \mathrm{Cr}-\mathrm{Ba}-\mathrm{O}(\text { nuclei }) \\
& \mathrm{Cr}-\mathrm{Ba}-\mathrm{O}(\text { nuclei })+\mathrm{CrO}_{3}(\mathrm{~g}) \rightarrow \mathrm{Cr}_{2} \mathrm{O}_{3}(\mathrm{~s}) \\
& \mathrm{Cr}_{2} \mathrm{O}_{3}(\mathrm{~s})+\mathrm{CrO}_{3}(\mathrm{~g})+\mathrm{BaO}(\mathrm{s}) \rightarrow \mathrm{BaCrO}_{4}(\mathrm{~s})
\end{aligned}
$$

Based on the products of Cr deposition, BSCF is preferred than LSCF and SSCF as the cathode material since its reaction product has relatively higher conductivity. Moreover, a protective coating layer on the interconnect to inhibit $\mathrm{Cr}$ diffusion and lower working temperature are viable options for SOFCs.

Usually, initial stoichiometry can be controlled by the ratio of reaction precursors. The optimal stoichiometry is the tradeoff between conductivity and structure stability. Lattice constant is affected by compositions and stoichiometry. More atoms in A-sites lead to smaller lattice constant [36]. Smaller lattice constant can lead to larger conductivity. Particle size is affected by many factors, such as synthesis method and temperature. Smaller particle size is beneficial for electrochemical performance. These factors play a major role on the initial cathode 
performance because $\mathrm{Cr}$ deposition is not significant at this point. At high temperature operation, $\mathrm{Cr}$ deposition is more significant and play a major role in the cathode performance. Also, stoichiometry, lattice constant, and particle size change with thermal treatment should be separately evaluated. Higher working temperature accelerates cathode activation and increases polarization resistance; however, the stabilized polarization resistance is smaller.

\section{Conclusions}

Three cathode materials, LSCF, BSCF, and SSCF, are compared for their electrochemical performance working at $600{ }^{\circ} \mathrm{C}, 700{ }^{\circ} \mathrm{C}$, and $800{ }^{\circ} \mathrm{C}$ and the corresponding microstructure and phase changes. The electrical conductivity of LSCF is the highest while that of BSCF is the lowest across this temperature range. All the cathodes reach the maximal electrical conductivity at $600-700{ }^{\circ} \mathrm{C}$. The BSCF cathode has the smallest polarization resistance at $600{ }^{\circ} \mathrm{C}$, comparable to the SSCF cathode; the LSCF cathode has the smallest polarization resistance working at $700{ }^{\circ} \mathrm{C}$; the SSCF cathode has the smallest polarization resistance working at $800{ }^{\circ} \mathrm{C}$, comparable to the LSCF cathode. $\mathrm{SrCrO}_{4}$ forms on the LSCF and SSCF cathodes next to the interconnect after $100 \mathrm{hrs}$ of the thermal treatment. For the $\mathrm{BSCF}$ cathode, only $\mathrm{BaCrO}_{4}$ is detected after working at $600-800{ }^{\circ} \mathrm{C}$ for $100 \mathrm{hrs}$, which is related to the larger atomic radius of $\mathrm{Ba}^{2+}$ ions. SSCF is more prone to chromium deposition than that of LSCF because of its smaller ionic radius.

\section{Acknowledgments}

The authors acknowledge the financial support from Office of Naval Research under grant number ONR N00014-14-1-0466. 


\section{References}

[1] A. Jun, S. Yoo, O.H. Gwon, J. Shin, G. Kim, Thermodynamic and electrical properties of $\mathrm{Ba}_{0.5} \mathrm{Sr}_{0.5} \mathrm{Co}_{0.8} \mathrm{Fe}_{0.2} \mathrm{O}_{3-\delta}$ and $\mathrm{La}_{0.6} \mathrm{Sr}_{0.4} \mathrm{Co}_{0.2} \mathrm{Fe}_{0.8} \mathrm{O}_{3-\delta}$ for intermediate-temperature solid oxide fuel cells, Electrochim Acta, 89 (2013) 372-376.

[2] P. Ried, P. Holtappels, A. Wichser, A. Ulrich, T. Graule, Synthesis and characterization of $\mathrm{La}_{0.6} \mathrm{Sr}_{0.4} \mathrm{Co}_{0.2} \mathrm{Fe}_{0.8} \mathrm{O}_{3-\delta}$ and $\mathrm{Ba}_{0.5} \mathrm{Sr}_{0.5} \mathrm{Co}_{0.8} \mathrm{Fe}_{0.2} \mathrm{O}_{3-\delta}$, J Electrochem Soc, 155 (2008) B1029B1035.

[3] D. Rembelski, J.P. Viricelle, L. Combemale, M. Rieu, Characterization and comparison of different cathode materials for SC-SOFC: LSM, BSCF, SSC, and LSCF, Fuel Cells, 12 (2012) 256-264.

[4] X.F. Ma, J.S.A. Carneiro, X.K. Gu, H. Qin, H.L. Xin, K. Sun, E. Nikolla, Engineering complex, layered metal oxides: High-performance nickelate oxide nanostructures for oxygen exchange and reduction, Acs Catal, 5 (2015) 4013-4019.

[5] C.S. Hsu, B.H. Hwang, Microstructure and properties of the $\mathrm{La}_{0.6} \mathrm{Sr}_{0.4} \mathrm{Co}_{0.2} \mathrm{Fe}_{0.8} \mathrm{O}_{3}$ cathodes prepared by electrostatic-assisted ultrasonic spray pyrolysis method, J Electrochem Soc, 153 (2006) A1478-A1483.

[6] R. Pelosato, G. Cordaro, D. Stucchi, C. Cristiani, G. Dotelli, Cobalt based layered perovskites as cathode material for intermediate temperature solid oxide fuel cells: A brief review, J Power Sources, 298 (2015) 46-67.

[7] H. Lee, J. Choi, I. Park, D. Shin, Electrochemical performance of continuously gradient composite cathode fabricated by electro-static slurry spray deposition, Int J Hydrogen Energ, 39 (2014) 14322-14327. 
[8] Z.G. Lu, J. Hardy, J. Templeton, J. Stevenson, Extended reaction zone of $\mathrm{La}_{0.6} \mathrm{Sr}_{0.4} \mathrm{Co}_{0.2} \mathrm{Fe}_{0.8} \mathrm{O}_{3}$ cathode for solid oxide fuel cell, J Power Sources, 198 (2012) 90-94.

[9] J.S. Kim, D.H. Yeon, D.W. Jung, C. Kwak, A highly active and long-term stable La-doped $\mathrm{Ba}_{\mathrm{x}} \mathrm{Sr}_{1-\mathrm{x}} \mathrm{Co}_{1-\mathrm{y}} \mathrm{Fe}_{\mathrm{y}} \mathrm{O}_{3-\delta}$ cathode for solid-oxide fuel cells, J Power Sources, 249 (2014) 66-71.

[10] Y.M. Park, J.H. Kim, H. Kim, In situ sinterable cathode with nanocrystalline $\mathrm{La}_{0.6} \mathrm{Sr}_{0.4} \mathrm{Co}_{0.2} \mathrm{Fe}_{0.8} \mathrm{O}_{3-\delta}$ for solid oxide fuel cells, Int J Hydrogen Energ, 36 (2011) 5617-5623.

[11] Z.P. Shao, S.M. Haile, A high-performance cathode for the next generation of solid-oxide fuel cells, Nature, 431 (2004) 170-173.

[12] Z.P. Shao, S.M. Haile, J. Ahn, P.D. Ronney, Z.L. Zhan, S.A. Barnett, A thermally selfsustained micro solid-oxide fuel-cell stack with high power density, Nature, 435 (2005) 795798.

[13] H. Lv, Y.J. Wu, B. Huang, B.Y. Zhao, K.A. Hu, Structure and electrochemical properties of $\mathrm{Sm}_{0.5} \mathrm{Sr}_{0.5} \mathrm{Co}_{1-\mathrm{x}} \mathrm{Fe}_{\mathrm{x}} \mathrm{O}_{3-\delta}$ cathodes for solid oxide fuel cells, Solid State Ionics, 177 (2006) 901906.

[14] J.W. Fergus, Lanthanum chromite-based materials for solid oxide fuel cell interconnects, Solid State Ionics, 171 (2004) 1-15.

[15] L. Zhao, J. Drennan, C. Kong, S. Amarasinghe, S.P. Jiang, Insight into surface segregation and chromium deposition on $\mathrm{La}_{0.6} \mathrm{Sr}_{0.4} \mathrm{Co}_{0.2} \mathrm{Fe}_{0.8} \mathrm{O}_{3-\delta}$ cathodes of solid oxide fuel cells, $\mathrm{J}$ Mater Chem A, 2 (2014) 11114-11123.

[16] X.L. Yang, H.Y. Tu, Q.C. Yu, Fabrication of $\mathrm{Co}_{3} \mathrm{O}_{4}$ and $\mathrm{La}_{0.6} \mathrm{Sr}_{0.4} \mathrm{CoO}_{3-\delta}-\mathrm{Ce}_{0.8} \mathrm{Gd}_{0.2} \mathrm{O}_{2-\delta}$ dual layer coatings on SUS430 steel by in-situ phase formation for solid oxide fuel cell interconnects, Int J Hydrogen Energ, 40 (2015) 607-614. 
[17] S.P. Jiang, X.B. Chen, Chromium deposition and poisoning of cathodes of solid oxide fuel cells - A review, Int J Hydrogen Energ, 39 (2014) 505-531.

[18] R.R. Mosbaek, J. Hjelm, R. Barfod, J. Hogh, P.V. Hendriksen, Electrochemical characterization and degradation analysis of large SOFC stacks by impedance spectroscopy, Fuel Cells, 13 (2013) 605-611.

[19] A. Evans, J. Martynczuk, D. Stender, C.W. Schneider, T. Lippert, M. Prestat, Lowtemperature micro-solid oxide fuel cells with partially amorphous $\mathrm{La}_{0.6} \mathrm{Sr}_{0.4} \mathrm{CoO}_{3-8}$ cathodes, Adv Energy Mater, 5 (2015).

[20] D.A. Medvedev, J.G. Lyagaeva, E.V. Gorbova, A.K. Demin, P. Tsiakaras, Advanced materials for SOFC application: Strategies for the development of highly conductive and stable solid oxide proton electrolytes, Prog Mater Sci, 75 (2016) 38-79.

[21] A.A. Asadi, A. Behrouzifar, M. Iravaninia, T. Mohammadi, A. Pak, Preparation and oxygen permeation of $\mathrm{La}_{0.6} \mathrm{Sr}_{0.4} \mathrm{Co}_{0.2} \mathrm{Fe}_{0.8} \mathrm{O}_{3-\delta}$ (LSCF) perovskite-type membranes: Experimental study and mathematical modeling, Ind Eng Chem Res, 51 (2012) 3069-3080.

[22] A. Petric, P. Huang, F. Tietz, Evaluation of La-Sr-Co-Fe-O perovskites for solid oxide fuel cells and gas separation membranes, Solid State Ionics, 135 (2000) 719-725.

[23] H.L. Zhao, W. Shen, Z.M. Zhu, X. Li, Z.F. Wang, Preparation and properties of $\mathrm{Ba}_{\mathrm{x}} \mathrm{Sr}_{1-}$ ${ }_{\mathrm{x}} \mathrm{Co}_{\mathrm{y}} \mathrm{Fe}_{1-\mathrm{y}} \mathrm{O}_{3-\delta}$ cathode material for intermediate temperature solid oxide fuel cells, J Power Sources, 182 (2008) 503-509.

[24] T.G. Jin, K. Lu, Chemical compatibility between Sr-doped lanthanum manganite air electrode and AISI 441 interconnect, Int J Hydrogen Energ, 36 (2011) 4440-4448. 
[25] G.S. Godoi, D.P.F. de Souza, Electrical and microstructural characterization of $\mathrm{La}_{0.7} \mathrm{Sr}_{0.3} \mathrm{MnO}_{3}$ (LSM), $\mathrm{Ce}_{0.8} \mathrm{Y}_{0.2} \mathrm{O}_{2}(\mathrm{CY})$ and LSM-CY composites, Mat Sci Eng B-Solid, 140 (2007) 90-97.

[26] K. Lu, F.Y. Shen, R. Roberts, G. Doucette, M. McGuire, W.L. Li, $(\mathrm{LaSr})_{\mathrm{x}} \mathrm{MnO}_{3}$ cathode stoichiometry effects on electrochemical performance in contact with AISI 441 steel interconnect, J Power Sources, 268 (2014) 379-387.

[27] Z.Y. Jiang, L. Zhang, K. Feng, C.R. Xia, Nanoscale bismuth oxide im, regnated ( $\mathrm{La}, \mathrm{Sr}) \mathrm{MnO}_{3}$ cathodes for intermediate-temperature solid oxide fuel cells, J Power Sources, 185 (2008) 40-48.

[28] A. Mai, M. Becker, W. Assenmacher, F. Tietz, D. Hathiramani, E. Ivers-Tiffee, D. Stover, W. Mader, Time-dependent performance of mixed-conducting SOFC cathodes, Solid State Ionics, 177 (2006) 1965-1968.

[29] M. Shah, P.W. Voorhees, S.A. Barnett, Time-dependent performance changes in LSCFinfiltrated SOFC cathodes: The role of nano-particle coarsening, Solid State Ionics, 187 (2011) 64-67.

[30] J. Park, J. Zou, H. Yoon, G. Kim, J.S. Chung, Electrochemical behavior of $\mathrm{Ba}_{0.5} \mathrm{Sr}_{0.5} \mathrm{Co}_{0.2-}$ ${ }_{x} \mathrm{Zn}_{\mathrm{x}} \mathrm{Fe}_{0.8} \mathrm{O}_{3-\delta}(\mathrm{X}=0-0.2)$ perovskite oxides for the cathode of solid oxide fuel cells, Int $\mathrm{J}$ Hydrogen Energ, 36 (2011) 6184-6193.

[31] W.L. Li, K. Lu, Z.B. Xia, Interaction of $\left(\mathrm{La}_{1-\mathrm{x}} \mathrm{Sr}_{\mathrm{x}}\right)_{\mathrm{n}} \mathrm{Co}_{1-\mathrm{y}} \mathrm{Fe}_{\mathrm{y}} \mathrm{O}_{3-\delta}$ cathodes and AISI 441 interconnect for solid oxide fuel cells, J Power Sources, 237 (2013) 119-127.

[32] K. Lu, F.Y. Shen, Effect of stoichiometry on $(\mathrm{La} 0.6 \mathrm{Sr} 0.4)_{x} \mathrm{Co}_{0.2} \mathrm{Fe}_{0.8} \mathrm{O}_{3}$ cathode evolution in solid oxide fuel cells, J Power Sources, 267 (2014) 421-429. 
[33] K.F. Chen, N. Ai, K.M. O'Donnell, S.P. Jiang, Highly chromium contaminant tolerant BaO infiltrated $\mathrm{La}_{0.6} \mathrm{Sr}_{0.4} \mathrm{Co}_{0.2} \mathrm{Fe}_{0.8} \mathrm{O}_{3-\delta}$ cathodes for solid oxide fuel cells, Phys Chem Chem Phys, 17 (2015) 4870-4874.

[34] X.B. Chen, L. Zhang, E.J. Liu, S.P. Jiang, A fundamental study of chromium deposition and poisoning at $\left(\mathrm{La}_{0.8} \mathrm{Sr}_{0.2}\right)_{0.95}\left(\mathrm{Mn}_{1-\mathrm{x}} \mathrm{Co}_{\mathrm{x}}\right) \mathrm{O}_{3 \pm \delta}(0.11 \leq \mathrm{x} \leq 1.0)$ cathodes of solid oxide fuel cells, Int J Hydrogen Energ, 36 (2011) 805-821.

[35] Y.M. Kim, X.B. Chen, S.P. Jiang, J. Bae, Effect of strontium content on chromium deposition and poisoning in $\mathrm{Ba}_{1-\mathrm{x}} \mathrm{Sr}_{\mathrm{x}} \mathrm{Co}_{0.8} \mathrm{Fe}_{0.2} \mathrm{O}_{3-\delta}(0.3 \leq \mathrm{x} \leq 0.7)$ cathodes of solid oxide fuel cells, J Electrochem Soc, 159 (2012) B185-B194.

[36] J. Emmerlich, B.M. Linke, D. Music, J.M. Schneider, Towards designing $\mathrm{La}_{1-\mathrm{x}} \mathrm{Sr}_{\mathrm{x}} \mathrm{Co}_{\mathrm{y}} \mathrm{Fe}_{1-}$ $\mathrm{y}_{3-\mathrm{d}}$ with enhanced phase stability: Role of the defect structure, Solid State Ionics, 255 (2014) 108-112. 


\section{Table captions}

Table 1. Detailed electrical conductivities of LSCF, BSCF, and SSCF.

Table 2. Resistances for the three cathodes after working at the three studied temperatures for 100 hrs. 


\section{Figure captions}

Fig. 1. Electrical conductivities of LSCF, BSCF, and SSCF from $300{ }^{\circ} \mathrm{C}$ to $900{ }^{\circ} \mathrm{C}$ in air.

Fig. 2. Electrochemical impedance spectroscopic plots of (a) LSCF cathodes, (b) BSCF cathodes, and (c) SSCF cathodes tested at $600{ }^{\circ} \mathrm{C}, 700{ }^{\circ} \mathrm{C}$, and $800{ }^{\circ} \mathrm{C}$ respectively after $2 \mathrm{hrs}$.

Fig. 3. Polarization resistance changes for the LSCF, BSCF, and SSCF cathodes at (a) $600{ }^{\circ} \mathrm{C}$, (b) $700{ }^{\circ} \mathrm{C}$, and (c) $800{ }^{\circ} \mathrm{C}$ with the thermal treatment time.

Fig. 4. Surface morphology of LSCF cathodes ((a), (d), (g), (j)), BSCF cathodes ((b), (e), (h), (k)), and SSCF cathodes ((c), (f), (i), (l)). (a), (b), (c) are from the initial samples before testing; (d), (e), (f) are from the tested cathodes at $600{ }^{\circ} \mathrm{C}$ for $100 \mathrm{hrs}$; (g), (h), (i) are from the tested cathodes at $700{ }^{\circ} \mathrm{C}$ for $100 \mathrm{hrs} ;(\mathrm{j}),(\mathrm{k}),(\mathrm{l})$ are from the tested cathodes at $800{ }^{\circ} \mathrm{C}$ for $100 \mathrm{hrs}$. All images have same scale.

Fig. 5. XRD patterns of (a) LSCF cathodes, (b) BSCF cathodes, and (c) SSCF cathodes at initial state and after $600{ }^{\circ} \mathrm{C}, 700{ }^{\circ} \mathrm{C}$, and $800{ }^{\circ} \mathrm{C}$ testing. 
Table 1

\begin{tabular}{c|c|c|c}
\hline Cathode & LSCF & BSCF & SSCF \\
\hline$\sigma @ 300{ }^{\circ} \mathrm{C}\left(\mathrm{S} \cdot \mathrm{cm}^{-1}\right)$ & 176 & 4 & 60 \\
\hline$\sigma_{\max }\left(\mathrm{S} \cdot \mathrm{cm}^{-1}\right)$ & 252 & 46 & 185 \\
\hline $\mathrm{T} @ \sigma_{\max }\left({ }^{\circ} \mathrm{C}\right)$ & 650 & 600 & 700 \\
\hline$\sigma @ 900^{\circ} \mathrm{C}\left(\mathrm{S} \cdot \mathrm{cm}^{-1}\right)$ & 220 & 16 & 122 \\
\hline
\end{tabular}


Table 2

\begin{tabular}{c|c|c|c|c|c|c|c|c|c}
\hline \multirow{2}{*}{ Cathode } & \multicolumn{3}{|c|}{ LSCF } & \multicolumn{3}{c|}{ BSCF } & \multicolumn{3}{c}{ SSCF } \\
\cline { 2 - 10 } & $600^{\circ} \mathrm{C}$ & $700^{\circ} \mathrm{C}$ & $800^{\circ} \mathrm{C}$ & $600{ }^{\circ} \mathrm{C}$ & $700^{\circ} \mathrm{C}$ & $800^{\circ} \mathrm{C}$ & $600^{\circ} \mathrm{C}$ & $700^{\circ} \mathrm{C}$ & $800^{\circ} \mathrm{C}$ \\
\hline $\mathrm{R}_{\mathrm{p}}\left(\Omega \cdot \mathrm{cm}^{2}\right)$ & 9.4 & 3.3 & 4.6 & 5.1 & 5.2 & 5.6 & 6.0 & 5.3 & 4.5 \\
\hline
\end{tabular}


figure 1

Temperature $\left({ }^{\circ} \mathrm{C}\right)$

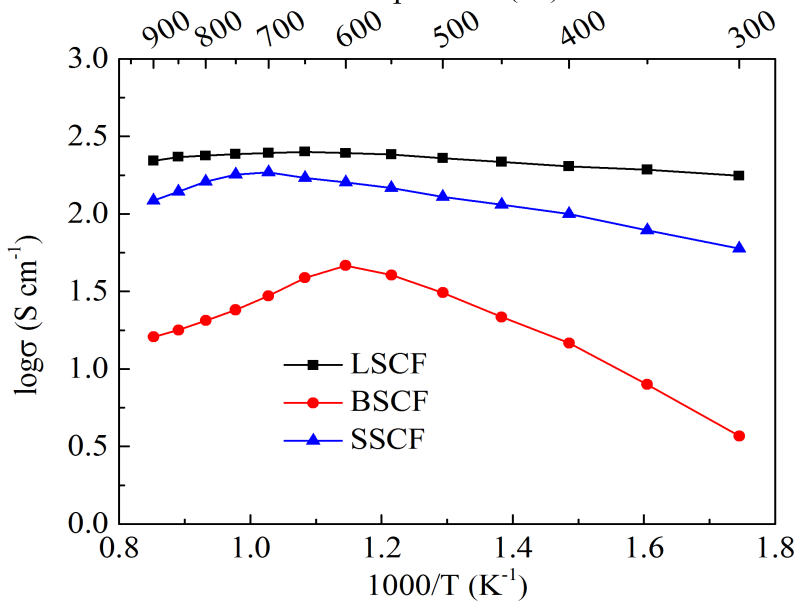




\section{figure $2 \mathrm{a}$}

(a)

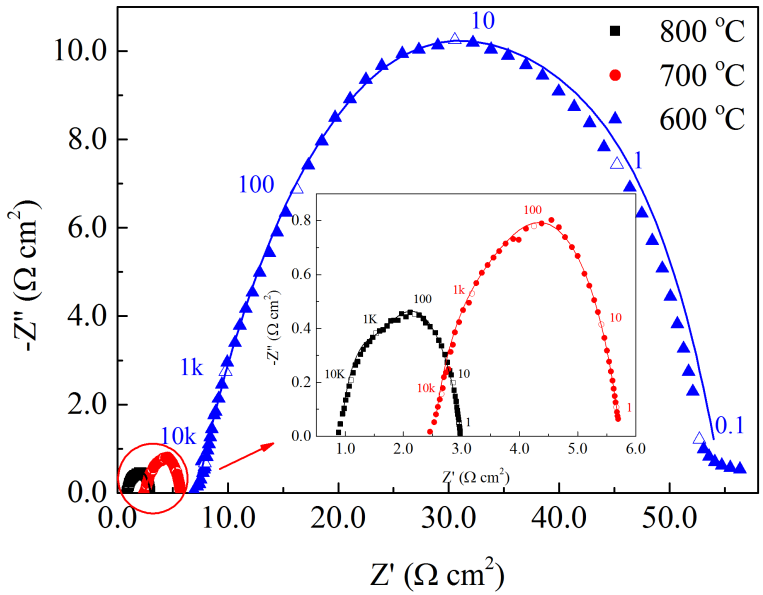


figure $2 b$

(b)

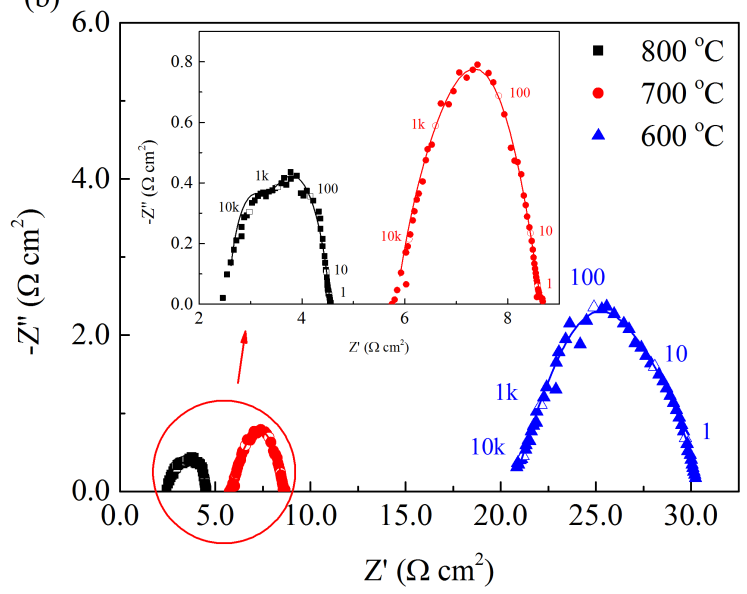


figure $2 c$

(c)

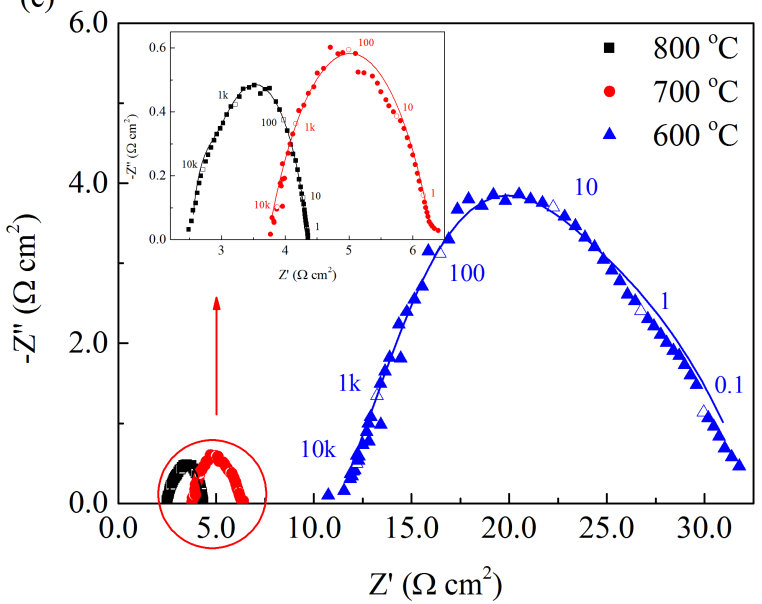


figure $3 \mathrm{a}$

(a)

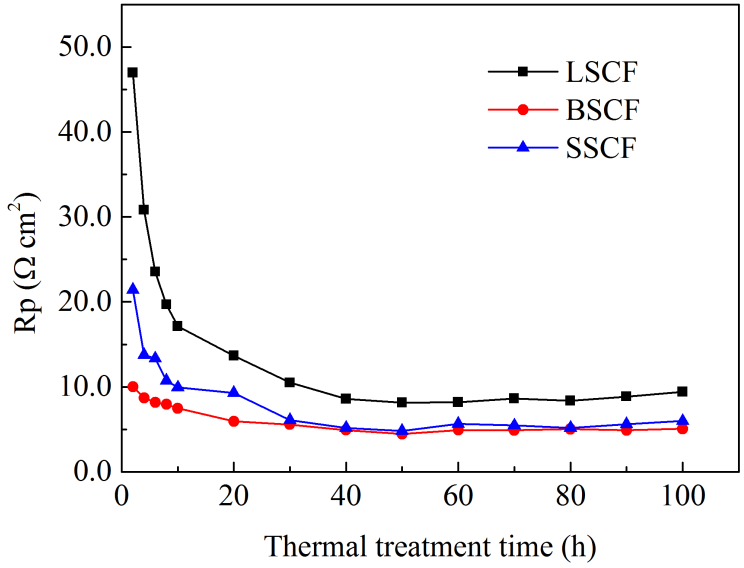


figure $3 b$

(b)

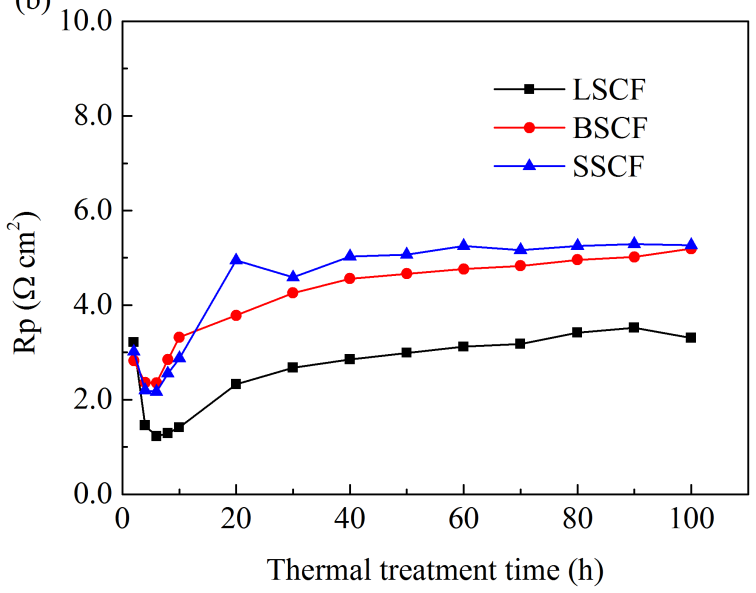


figure $3 c$

(c)

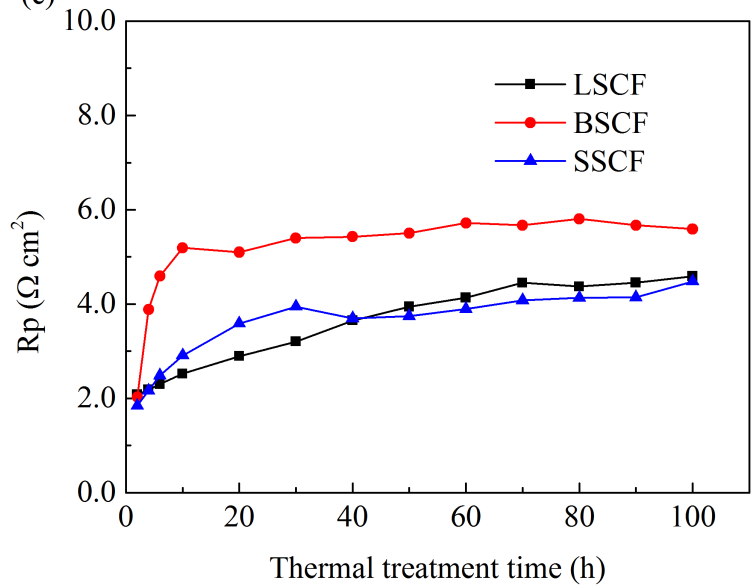


figure 4

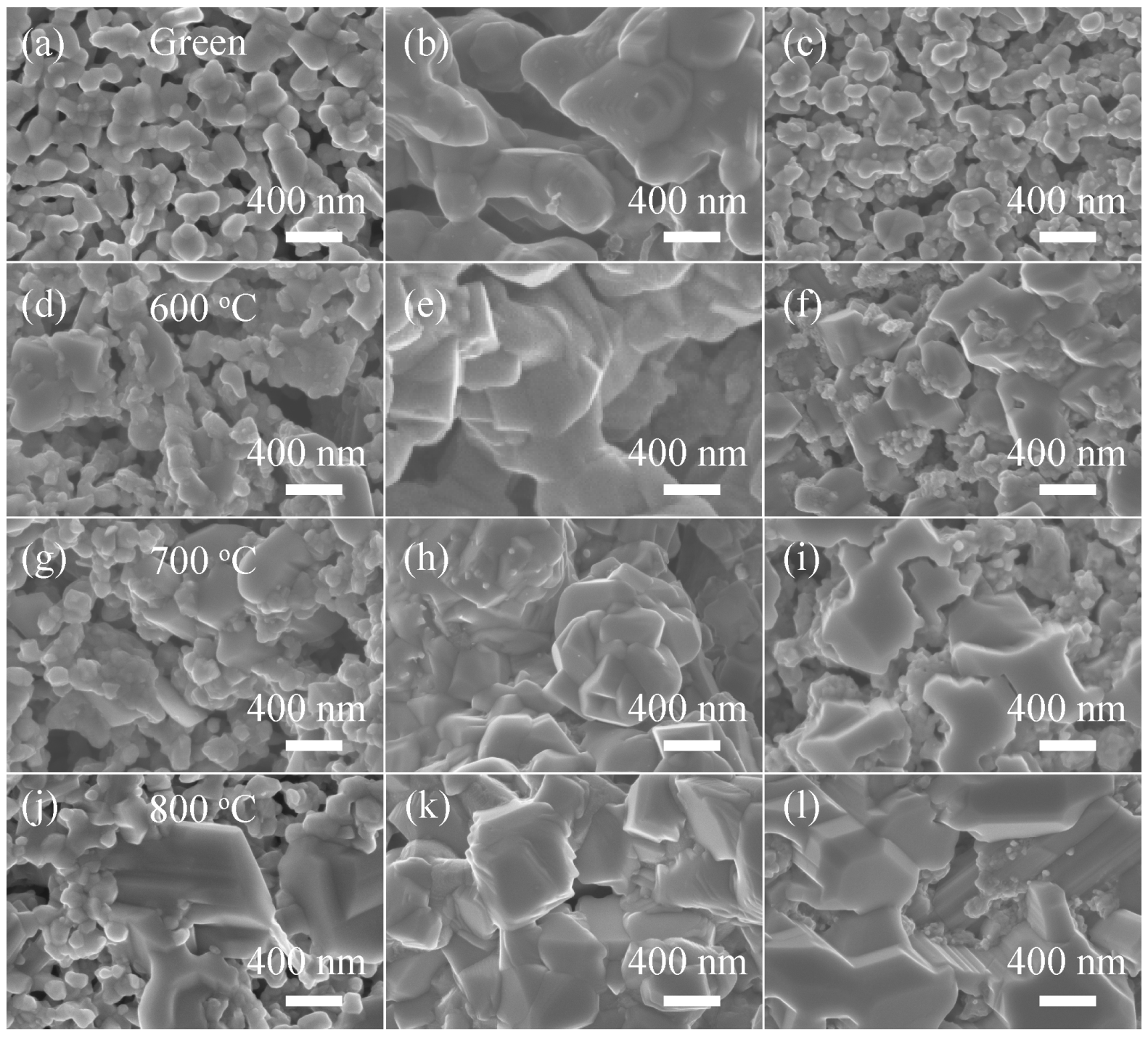




\section{figure $5 a$}

(a)

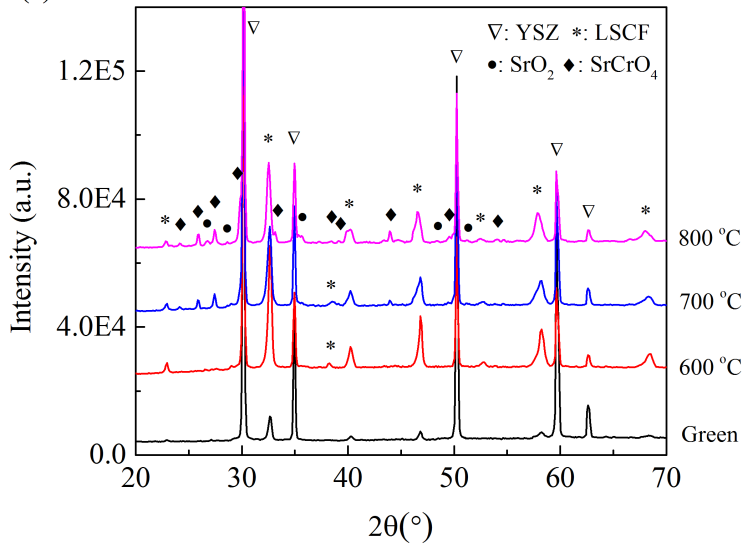




\section{figure $5 b$}

(b)

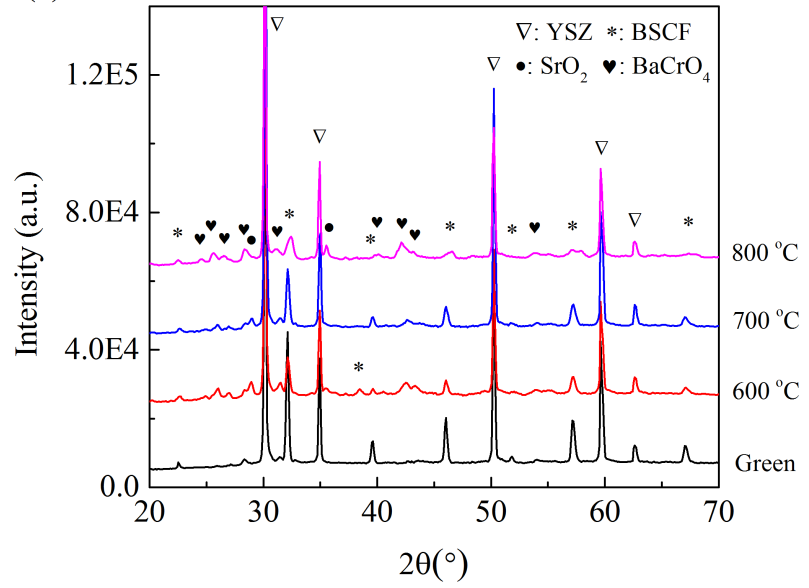


figure $5 c$

(c)

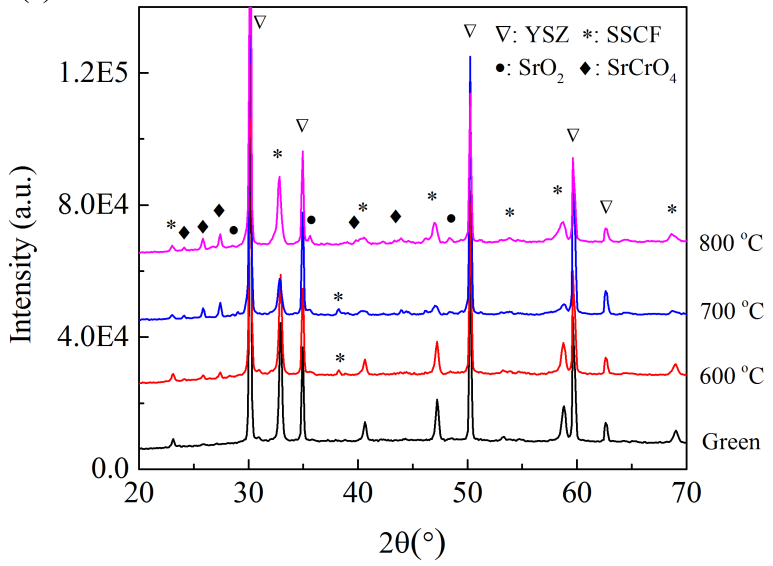


figure 6

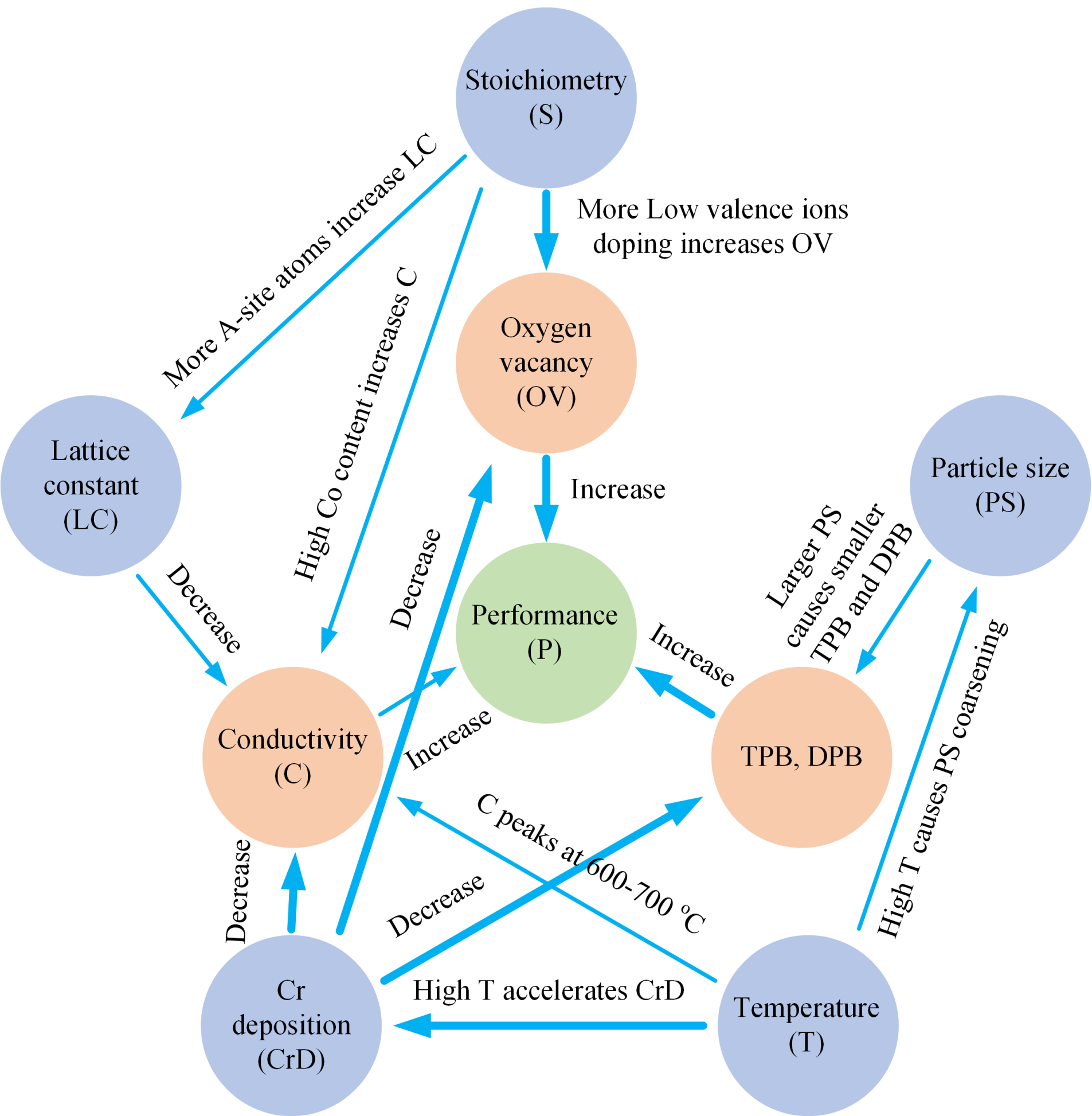

